\title{
Thinking skills and communicative language teaching: a curriculum perspective
}

\section{J.J. Swartz}

The author assesses the impact that the communicative approach has had on English Second Language teaching in South Africa and concludes that many L2 teachers have resisted using this approach. This may be attributed to a misunderstanding of the basic principles of communicative language teaching (CLT), as well as to uncertainty regarding its practical application. He proposes an innovative way of implementing CLT, involving the integration of thinking skills with selected language content within a communicative framework. To demonstrate this, he gives a detailed description of a language teaching module for senior secondary pupils. He then discusses the communicative nature of the activities contained in the module and points out what additional benefits this approach may offer L2 pupils.

Die skrywer evalueer die impak wat die kommunikatiewe benadering op Engels tweede taalonderrig in Suid-Afrika gehad het en kom tot die gevolgtrekking dat menige tweede taalonderwysers teenstand bied teen die gebruik van dié benadering. Dit kan toegeskryf word aan die feit dat daar ' $n$ wanbegrip bestaan van die basiese beginsels van kommunikatiewe taalonderrig, asook 'n onsekerheid rakende die praktiese toepassing daarvan. Hy stel 'n innoverende wyse van aanbieding voor wat die integrasie van denkvaardighede met geselekteerde taalinhoude binne 'n kommunikatiewe raamwerk behels. Om dit te demonstreer gee hy 'n gedetailleerde beskrywing van 'n taalonderrigmodule vir senior sekondêre leerlinge. Daarna bespreek hy die kommunikatiewe aard van die aktiwiteite wat die module bevat en dui ook aan watter addisionele voordele hierdie benadering vir tweede taal-leerlinge inhou.

It has been almost a decade since second and foreign language teachers worldwide started to adopt what has come to be known as the communicative approach in their classrooms. Now that the initial euphoria which greeted this approach has abated, and much of the confusion surrounding its actual implementation has been cleared, it would seem appropriate to try to assess the impact and practical success of communicative language teaching (CLT) in South Africa.

It is my impression that CLT has met with a great deal of resistance from second language teachers. I confine my observations to the Cape Province of South Africa, a large area with which I am familiar and which, together with other provinces, revised its Second Language English Syllabi for Secondary Schools to accommodate CLT in 1986. In addition to syllabus revision and guidelines, an abundance of articles on the rationale for CLT were available to $\mathbf{L} 2$ teachers, in-service training courses were held, and education faculties responsible for training new teachers acknowledged this important shift of focus by giving CLT a prominent place in their didactics courses. 
In 1988/89, I administered a questionnaire to a large number of EL2 teachers at secondary schools throughout the Cape Province (mainly rural areas). In 1990 a similar questionnaire on a much smaller scale was completed by EL2 teachers in the Western Cape (Bellville, Parow, Goodwood) as part of an empirical study for a Master's degree. The results were remarkably similar, revealing large scale teacher resentment of this change in approach. Of the many and varied reasons given for this negative reaction, I mention only the commonest.

- Teachers were unsure how to implement CLT.

There were (initially) no text books written with this approach in mind; consequently, teachers had to devise their own materials.

- $\quad$ Teachers felt they needed to be trained in the use of CLT.

- The approach was considered too unstructured and informal.

- The approach required active use of the target language in the classroom, and teachers complained that shy, weaker pupils felt intimidated and were unwilling to participate.

- Lack of faith was expressed in a method which, according to the perceptions of many, denied the role of formal language study in L2 learning.

- Communicative testing was considered impracticable, and this seemed to reflect negatively on the teaching method.

- Many teachers regarded CLT as just another bandwagon which, they believed, would soon grind to a halt.

These findings seem to suggest that CLT has not had the hoped for reception amongst L2 teachers in South Africa. (It is unlikely that the reactions of teachers in the Cape Province would differ radically from those in the other three provinces.) A closer scrutiny of the reasons given for this opposition suggests that they could be reduced to two broad ones: a misunderstanding of the essence of the approach, and ignorance of how to apply it in practice. The result has been that teachers tend to ignore syllabus prescriptions, and cling to safe, tried and traditional methods in which the mastery of grammatical structures, stilted language exercises, oral drills, prepared oral presentations, and literature studied in isolation, play a prominent role. Old habits, as we know, die hard.

The question is: can this situation be rectified, and if so, how?

Many of the misperceptions that teachers are guilty of regarding CLT stem ironically from one of the great virtues of the approach. I refer to the fact that CLT is not a teaching method (in the fairly rigid sense of the word), but rather a comprehensive teaching approach, able to accommodate a wide range of activities and methods within its ambit. This approach does not preclude the use of error correction, formal grammar exercises and explanations, or situational dialogues, when considered necessary. These may, in fact, be essential to pupils whose learning style demands that type of knowledge or practice. But while these may have a role in the communicative approach, they do not represent the essence of CLT.

Once the exclusive use of traditional grammar-based methods had been discredited (no difficult task), something very different had to be proposed to replace it. What emerged from the early writings of Widdowson (1978), Brumfit and Johnson (1979), Littlewood (1981), Nunan (1983) and others, was a set of guidelines aimed at helping teachers design authentic communicative language activities. According to these guidelines, authentic communication occurs only when

the speaker really has something to say 
- the speaker has a need or desire to speak, for whatever purpose

- the listener is interested in what he hears, i.e. a 'want-to-know' situation

- an information-gap exists, i.e. the listener is unaware of what the speaker is about to say, which in turn implies that his (the listener's) response is unplanned and spontaneous

- $\quad$ the focus is on content, i.e. getting the message across, rather than on grammatical form

- the speaker uses the full store of language available to him, not just selected language structures.

These criteria proved extremely useful to those teachers willing and imaginative enough to design their own materials and activities. The result was that in these EI 2 classrooms, pupils were motivated to use the target language to communicate ideas and opinions, and to work in groups to solve problems or determine a course of action, often aided by realia which enhanced the authenticity of the activity.

Unfortunately, the elimination of misperceptions regarding CLT and the provision of clear guidelines for the design of communicative activities are not guaranteed to soften the attitudes of the many teachers who feel threatened by innovation, and who insist on being given a series of lesson plans ready to be implemented in the classroom, in the way that traditional grammar texts had provided endless language exercises to keep the pupils busy (though not productive). The syllabus provides no such plan, and the few text books which have been written for the communicative approach cannot be used as a crutch by the teacher, as was the case in the past.

As indicated earlier, CLT is a very broad-based approach which can accommodate a wide spectrum of methods and activities. At the risk of adding to the confusion that teachers may still experience, I would like to propose an innovative way of implementing CLT in the EL2 classroom, and it is to this end that I devote the rest of this article.

I wish to make it clear from the outset that what I am about to propose is by no means the only, or even the best way of putting CLT into practice. However, the activities in the module that I will describe all conform to the guidelines for CLT referred to earlier; are likely to motivate pupils to participate freely; may be adapted for use at virtually any level, and could serve as a model for unlimited variations to this approach - variations which the teacher should have no difficulty in devising.

My proposal is that the teaching of selected thinking skills should be integrated with specific language content within a communicative approach to EL2 teaching.

It has long been acknowledged that language is the key to learning, that thought without language is unthinkable. It is not possible to encode one's thoughts, store them in the memory, and retrieve them when needed, without using language. As language and thinking are virtually inseparable, their combination in the classroom occurs naturally.

Puhl (1990) has the following to say about this combination:

Combining language and thinking seems a powerful and efficient way to improve curriculum at many levels, to ensure relevance, and to let the two components enhance each other in an educational endeavour that is greater than the sum of its parts ... The teaching of thinking skills and language teaching share a common ground in method, where they are best taught by pair and group interaction. 
In recent years, definitions of intelligence have changed to accommodate the hypothesis that thinking can be explicitly taught and learned. Thus a thinking skill, also called a tool, would be one that is learned and used in a conscious, deliberate way.

A person using thinking skills to solve a problem will not take the first solution as the only one and then put energy into defending that choice. Such a person will broaden his perceptions of the problem, possibly define requirements of a solution, come up with alternatives, and choose the best one(s).

(Puhl 1990:422)

For the purposes of the module described in this article, the thinking skills have been chosen from Edward de Bono's CoRT materials (1986). The tools used will be explained briefly before discussing how they could be integrated with language content. It is not the aim of this article, however, to argue the case for teaching thinking as an end in itself. The use of thinking skills is advocated to give substance to communicative activities aimed at promoting language learning.

The following module is suggested for pupils at the senior secondary level, and makes use of five de Bono thinking tools. The module consists of five phases or lessons.

\section{Theme of the module}

At this level something stimulating and contemporary must be selected. A controversial topic with which pupils are at least familiar usually works well. In 1990 when I devised this module, Nelson Mandela had just been released, and this local event, which made international headlines, proved an ideal choice.

\section{Aims of teaching the module}

Several aims can be identified.

- To give pupils the opportunity to communicate spontaneously in English

- To enable pupils to understand five thinking tools and to apply them in an authentic situation in order to decide on the best course of action to take

- To give pupils practice in using specific language functions such as agreeing, disagreeing, affirming arguments, setting conditions, explaining and describing

- To focus pupils' attention on selected language structures such as the use of IF in conditional clauses, and the use of the past perfect

- To expose pupils to selected vocabulary related to a specific theme

- To foster pupils' interest in current affairs by requiring them to read widely on a specific topic

- To give pupils practice in structuring arguments, both orally and in written form.

\section{Integration of language skills}

The communicative approach favours the integration of language skills. In this module pupils are required to (a) do functional reading, (b) listen carefully in order to respond to arguments, (c) exchange information and express opinions orally, and (d) prepare 
written reports, arguments, or letters to the press. All four language skills are thus involved naturally, as in real life.

\section{Teaching the thinking tools}

Although the focus here is on the mastery of specific thinking skills, the tools are taught through the medium of English, thus exposing the pupils to a wide range of vocabulary and language structures in keeping with the principles of CLT. This phase is also a carefully focused listening exercise.

In order to understand how the thinking skills are integrated with the language materials, it is necessary to describe those skills included in the module, as they are explained to the pupils.

$\mathrm{PNI}, \mathrm{C}+\mathrm{S}$, and $\mathrm{AGO}$ are classified as understanding tools.

PNI stands for Positive, Negative, and Interesting. It is a tool for considering ideas, suggestions, and proposals. It helps us decide whether we like or dislike an idea, or if we approve or disapprove of it. Instead of deciding immediately, we make an intentional effort to find and list the positive or plus points, the negative or minus points, and the interesting points.

$C+S$ stands for Consequences and Sequels. It requires one to look ahead to consider what will happen after some plan, decision, rule, or invention has been made or some action has taken place. The use of this tool enlarges one's view to include the immediate effect of an action which one may be contemplating.

$A G O$ stands for Aims, Goals, and Objectives. This tool emphasizes the idea of purpose. It investigates the reasons and motives for doing things.

$A P C$ is classified as a transforming tool. It stands for Alternatives, Possibilities, and Choices. It helps one to look beyond the obvious courses of action and deliberately explore other possibilities, alternatives, and choices as an antidote to emotional reactions. It transforms rigid thinking into creative thinking.

$A D I$ is classified as a tool for evaluation. It stands for Agreement, Disagreement, and Irrelevance. Its aim is to eliminate the irrelevant aspects of opposing ideas or arguments to increase the areas of agreement and reduce areas of disagreement. It helps one to discover that arguments are seldom absolutely correct or absolutely wrong.

The teaching of these (and many other) tools should be staggered over a period of time. After each tool has been explained, pupils are given an opportunity to apply it in a given situation which is discussed in groups. Finding solutions or deciding on a course of action by comparing and exchanging ideas with other group members is in itself a useful communicative activity.

\section{Phase 1 of the module}

Pupils are told beforehand to collect newspaper and magazine articles on the life of Nelson Mandela, his trial, imprisonment, release, speeches made, world reaction, ANC SA Government relations, etc. (Depending on how "current" the choice of theme is, these should be readily available.) 
The class is divided into two camps: those opposed to Mr Mandela's release, and those in favour of it. Each camp could consist of two or three groups of pupils working together, depending on the size of the class.

The groups are told that they will be expected to prepare comprehensive arguments reflecting their point of view, for use in a debate. The tools they would need to do this are then reviewed, viz. PNI, $\mathrm{C}+\mathrm{S}$, and AGO. These tools will be applied in the second phase of the module when all the relevant information has been collected and collated.

\section{Phase 2}

The groups pool the information they have collected and classify it in terms of its usefulness. With this information at their disposal (i.e. after articles have been read and discussed), each group uses the PNI tool to consider and list all the positive, negative and interesting aspects of Mr Mandela's release.

Thereafter the $\mathrm{C}+\mathrm{S}$ tool is applied. This requires the groups to consider the consequences of (a) releasing Mr Mandela from prison, and (b) not releasing him.

Finally, the groups use AGO to determine the possible aims and motives for releasing him, or keeping him in captivity.

In all cases, decisions reached must be based on the information available and must be well supported. The structuring of ideas and facts as a result of using these tools makes it easier to arrive at a decision or a well-founded opinion. In the course of doing so, pupils will need to communicate freely, express opinions, agree or disagree with other group members, follow arguments, explain and defend their own views, and express various emotions. They will also need to know and use particular vocabulary in order to do so. In their eagerness to contribute to the group effort, the focus will almost certainly be on content, i.e. getting their message across, rather than on grammatical form. Language errors made in the course of this discussion are not corrected.

One member of the group is required to record the group's views and the evidence supporting these views.

\section{Phase 3}

The APC tool is revised with the class. They are then told to apply this tool to the situation in order to obtain a clearer assessment of it and to justify and develop their point of view. The questions they would need to ask are: what alternatives to the release of Mr Mandela could the Government have considered? (For example, he could have been deported, given the death penalty for treason, been granted conditional release, confined to certain areas, etc.)

In anticipation of particular language structures being needed to express opinions in the course of the discussion, the teacher may draw attention to, for example, the use of IF in conditional clauses (given the context, it is likely to be used), and the correct use of the past perfect tense. Sentences such as the following may well be used:

- If Nelson Mandela had not been released, there would not have been so much violence in the country.

After Mr Mandela had been released, many countries were prepared to lift sanctions against South Africa. 
Each group is then instructed to choose a spokesman to represent it in a panel which will debate the issue. The group is responsible for preparing its spokesman's argument, after which the groups serving on the same panel must liaise to co-ordinate their arguments. The two panels must be thoroughly prepared for the debate in the next phase.

\section{Phase 4}

Before the debate is held, the teacher instructs all pupils to take notes on the main arguments presented by each side. The notes will play a significant role in the next activity. Thus note-taking (or summarising) becomes a very functional listening and writing activity in this context.

Once the debate has been completed, the teacher reviews the evaluation tool ADI with the class. The groups then reconvene and apply the tool to the opposing arguments expressed in the debate. This means that they must examine and explain points of agreement, disagreement, and irrelevance in the arguments, in an effort to find common ground and possibly reconcile the opposing views.

The two panels then report on their camp's findings after applying the ADI tool, and the main arguments are recapped. Again pupils are told to listen carefully as they will need to use these arguments in a written activity planned for the final phase.

\section{Phase 5}

The written activity is preceded by the teacher's input on constructing logical and coherent written arguments. Ways of linking and supporting ideas in order to strengthen an argument must be illustrated. Attention should be drawn to particular language devices (logical connectors, reference devices) which facilitate this.

The pupils are then assigned roles. They may be editors of newspapers taking a particular stand on the release of Mr Mandela in an editorial comment; they may be expressing their views in a letter to the press, or they may represent either pro- or antiANC sentiments in a written speech to be delivered before a hostile audience. In all of these, their arguments would need to be both coherent and convincing.

\section{A model for communicative language teaching}

Why should the module described above be considered a sound model for CLT?

In the first place, a careful examination of the proposed activities reveals that they conform to the six guidelines for authentic communication: in order to carry out the tasks set, pupils will have to make decisions in their groups which require a spontaneous exchange of ideas with the focus on content rather than grammatical form of expression; they will indeed have views to express, a desire to express them, and a need to listen to the unprepared views of members in their group. Finally, in expressing themselves in this context, they will necessarily use a wide range of language structures and vocabulary, and not the stilted language of, for example, oral drills.

Secondly, everything the pupils are required to do can be considered purposeful. Each stage of the module serves a purpose which is explained to pupils beforehand, e.g. using the thinking skills in order to prepare an argument to be presented in debate; taking notes in order to apply the ADI tool to the panel's arguments; gathering information in order to prepare a written argument in the form of an editorial or letter. 
Thirdly, as explained earlier, the module fully integrates the language skills of listening, speaking, reading, and writing in a non-contrived way.

Fourthly, the approach is decidedly pupil-centred. This is not to suggest that the teacher has no role, nor even an unimportant one. The teacher needs to motivate pupils, supply purpose for the activities, guide and assist when needed, give the necessary formal input when required, and evaluate the pupil product at various stages of the module. But throughout the module, the pupil is actively involved in using the language meaningfully. At the same time, pupil motivation is enhanced.

Fifthly, in keeping with the view that CLT is not a rigid method, but a broad-based approach, the module accommodates formal input by the teacher when required, e.g. on the use of the past perfect and the conditional IF, and on how to construct logical, coherent argument. The teaching and application of the selected thinking tools also fit in naturally with the communicative activities.

Sixthly, the module may be modified for use at virtually any level. Even primary school pupils learning English as a second language can hold group discussions and apply the simple thinking tools, given an appropriate context. Obviously a simpler theme would be chosen, and the language input and written activities would be adapted to their level. It is clear, too, that the choice of stimulating themes is endless. In 1991 it would be appropriate for senior secondary pupils to debate the violence occurring in South Africa, its causes and possible solutions. In collecting relevant material for this purpose, they would be tying up with their study of history, and be using language across the curriculum.

In conclusion, the question is posed again: why include thinking skills as part of the proposed communicative approach?

I have tried to demonstrate in the module described above that the use of the five tools in this context adds both purpose and structure to the activities set. It has always been my belief (and this has been confirmed by other EL2 teachers) that merely assigning pupils to a group and giving them a topic to "discuss" is no guarantee that what ensues is authentic communication involving the spontaneous use of the second language. Such group discussions are often characterised by long silences or lapses into the mother tongue. When the pupils have specific, appropriate instruments with which to analyse information, enabling them to reach decisions according to pre-determined guidelines, they work more meaningfully and constructively, and are able to justify the views and decisions they produce. Furthermore, if the theme chosen by the teacher is appropriate for the class, the use of the thinking skills will ensure that the ensuing discussions are never contrived.

Just as the choice of themes or topics for discussion is endless, so is the choice of thinking skills. De Bono's CoRT materials, contained in 6 volumes, are a systematic compilation of 60 thinking skills. In addition there are the thinking curricula developed at Harvard University, Odyssey (Adams 1986), and the instruments of Reuven Feuerstein (1980). This is a more than adequate store for the teacher who is willing to incorporate the use of thinking skills into the second language curriculum. The choice of tools, as with the selection of topics, vocabulary, and language input, is determined by the needs and level of the target group.

Not only does the teaching of these thinking tools expose L2 pupils to a broader spectrum of language than would otherwise be the case (and exposure to language in use is central to CLT), but the tools have such a wide use that new applications will readily suggest themselves to the teacher in search of meaningful communicative activities. The tools may be used singly, as in the model described, or in more complex combinations to preșent a stimulating challenge to brighter pupils at higher levels. 
From the above discussion it should be apparent that the use of thinking skills must not be seen as a second language teaching method, but rather as an aid to the implementation of CLT, which deserves serious consideration. It should also be noted, however, that although the teaching of thinking skills, as described in this article, is not an end in itself, there is the very real possibility that it will serve an educational goal beyond that of second language acquisition. For if the skills learned in the language classroom are transferred to other subjects, the language teacher will also have made a significant contribution to fostering the overall cognitive development of the pupils.

\section{REFERENCES}

ADAMS, M.J., et al. 1986. Odyssey, a curriculum for thinking. Watertown, Massachusetts: Mastery Education Corporation.

BRUMFIT, C.J. and K.J. Johnson, (Eds.) 1979. The communicative approach to language teaching. OUP: Oxford.

DE BONO, E. 1976. Teaching thinking. New York: Pergamon Press.

DE BONO, E. 1986. CoRT thinking 1-6. New York: Pergamon Press.

FEUERSTEIN, R. 1980. Instrumental enrichment: theoretical basis, goals, and instruments. The Educational Forum, May, 401-423.

LITTLEWOOD, W. 1981. Communicative language teaching: an introduction. CUP: Cambridge.

NICKERSEN, R., D. Perkins, and E. Smith. 1985. The teaching of thinking. Hillsdale, New Jersey: Lawrence Erlbaum Associates, Publishers.

NUNAN, D. 1983. Papers in TESL Methodology. London: Language Press.

PUHL, C. 1990. Teaching thinking to promote language acquisition: rationale. National Subject Didactics Symposium, 421-430. University of Stellenbosch.

STERNBERG, R.J. 1987. Teaching thinking skills: theory and practice. New York: W.H. Freeman and Co.

WIDDOWSON, H.G. 1978. Teaching language as communication. OUP: Oxford. 